\title{
ANALISIS KEPUASAN PENGGUNAAN SISTEM INFORMASI PERKREDITAN (STUDI KASUS: KOPERASI PERUMAHAN WANABAKTI NUSANTARA)
}

\author{
M. Fajriyansyah S. ${ }^{1}$ \\ BINUS Business School \\ Edi Abdurachman ${ }^{2}$ \\ BINUS Business School
}

\begin{abstract}
In the dynamic aviation business, change is a difficult thing to avoid, especially when it comes to the use of information technology. However, when information technology has been used, many problems can emerge and it is important to comply with the needs and expectations of management, as the company has often allocated large budgets for development. The users also need to know whether it meets their expectations or not.

Measurements will be performed by comparing the independent variables of Informativeness, Information Format, Ease of Use, Timeliness and Reliability, as well as user aspects divided into a wide variety of factors, namely Age, Work Experience, , Background Department of Education, Training, and Old Computer Usage. Analysis was conducted on the gap analysis, linear regression analysis, and chi-square analysis.

From the analyses there was found to be a significant gap between performance and user expectations in the KPWN credit information system. The regression analysis found that the only variable significantly related to user satisfaction was Reliability, and the chisquare analysis found that Educational Background significantly influenced user satisfaction.
\end{abstract}

\footnotetext{
${ }^{1}$ Alumni of BINUS Business School

${ }^{2}$ Faculty of BINUS Business School (edia@binus.edu)
} 
Keywords: informativeness, information format, easy of use, timeliness, reliability.

\begin{abstract}
ABSTRAK
Di dalam suatu bisinis yang dinamis, perubahan merupakan suatu hal yang susah untuk dihindari. Terutama bila berkaitan dengan penggunaan Teknologi Informasi, perkembangan teknologi yang semakin hari semakin cepat tentunya akan banyak membantu pelaku bisnis menjadi lebih efisien. Namun ketika tekonologi informasi telah digunakan, banyak permasalahan yang akan bermunculan dan keraguan apakah memang sistem informasi yang telah dibuat telah memenuhi kebutuhan dan harapan dari manajemen dimana perusahaan telah mengeluarkan biaya yang besar untuk pengembangannya. Dari sisi pengguna juga perlu diketahui, apakah sudah memenuhi harapan atau belum.

Pengukuran akan dilakukan dengan membandingkan variabel independen dan dependen, dimana variabel independen yang digunakan adalah aspek Informativeness, Information Format, Easy of Use, Timeliness, dan Reliability, serta aspek user background yang dipisah menjadi berbagai macam faktor-faktor yaitu Usia, Pengalaman Kerja, Latar Belakang Pendidikan Formal, Latar Belakang Jurusan Pendidikan, Pelatihan, dan Lama Penggunaan Komputer. Analisis yang dilakukan meliputi analisis kesenjangan, analisis regresi linier, dan analisis chi-square.

Dari hasil analisis yang ada ternyata didapati bahwa masih ada kesenjangan yang signifikan antara kinerja dan harapan pengguna system informasi perkreditan di KPWN, untuk analisis regresi ternyata didapati bahwa variable yang berhubungan secara signifikan terhadap kepuasaan pengguna hanya variable reliability, dan pada analisis chi-square ditemukan bahwa variable latar belakang pendidikan berpengaruh signifikan terhadap kepuasan pengguna.
\end{abstract}

Kata Kunci: informativeness, information format, easy of use, timeliness, reliability. 


\section{PENDAHULUAN}

Di dalam suatu bisinis yang dinamis, perubahan merupakan suatu hal yang susah untuk dihindari. Terutama bila berkaitan dengan penggunaan Teknologi Informasi, perkembangan teknologi yang semakin hari semakin cepat tentunya akan banyak membantu pelaku bisnis menjadi lebih efisien. Namun ketika tekonologi informasi telah digunakan, banyak permasalahan yang akan bermunculan dan keraguan apakah memang sistem informasi yang telah dibuat telah memenuhi kebutuhan dan harapan dari manajemen dimana perusahaan telah mengeluarkan biaya yang besar untuk pengembangannya. Dari sisi pengguna juga perlu diketahui, apakah sudah memenuhi harapan atau belum.

Koperasi Perumahan Wanabakti Nusantara (KPWN) merupakan lembaga usaha berbentuk koperasi yang didirikan pada tahun 1989, dengan maksud untuk meningkatkan kesejahteraan pegawai Departemen Kehutanan (DEPHUT) khususnya di bidang perumahaan dan kendaraan roda dua. Sampai saat ini, jumlah debitur telah mencapai sekitar 15.000 orang atau kurang lebih 36\% pegawai negeri sipil Departemen Kehutanan yang berada di pusat (Jakarta) ataupun daerah-daerah di seluruh Indonesia. Kebijakan penghentian pembangunan rumah dinas di tengah pesatnya pembangunan ekonomi dan terus bertambahnya jumlah pegawai memang menjadi masalah tersendiri.

Padahal, rumah adalah kebutuhan primer yang paling sulit dipenuhi oleh PNS dibandingkan kebutuhan lainnya, sandang dan pangan. Itu sebabnya tak jarang terdengar kasus-kasus menyedihkan yang menima PNS yang telah purna tugas tapi tidak bisa memiliki rumah.

Sebelum dibangun sistem informasi perkreditan KPWN, sistem kerja yang berjalan di setiap divisi KPWN berjalan dengan sendiri-sendiri. Banyaknya nasabah yang harus ditangani dan pekerjaan yang masih dilakukan dengan sistem manual seringkali membuat pekerjaan yang ada menjadi tidak efisien serta terjadi beberapa penumpukan data nasabah serta tidak sesuainya data angsuran dan cicilan. Sehingga ketika terjadi masalah, seringkali staf di divisi kredit harus menelusuri ulang data-data nasabah yang pada akhirnya akan memakan waktu dan membuat proses pengajuan kredit dari debitur menjadi terhambat. 
Mengingat banyaknya jumlah debitur yang ditangani serta luasnya cakupan wilayah kerja KPWN, pada tahun 2006 mulai dilakukan rencana pembangunan system informasi perkreditan untuk mengintegrasikan semua proses serta mengefisienkan pekerjaan yang ada di setiap divisi. Selain itu, dengan adanya sistem informasi yang baik diharapkan dapat meningkatkan pengawasan internal terhadap data-data nasabah, meningkatkan pelayanan kepada nasabah, serta dapat digunakan sebagai dasar untuk pengembangan sistem informasi yang menjadi lebih baik lagi di masa depan seperti pengembangan sistem berbasis Internet untuk nasabah di seluruh daerah.

Selain itu, sistem informasi yang telah ada saja tidak cukup membantu bila tidak didasari dengan kenyamanan para pengguna sistem dalam menjalankan sistem informasi yang ada. Bagaimana respon para pengguna sistem informasi, apakah sudah terpenuhi harapan para pengguna? Di bagian manakan yang menjadi masalah? Dan faktor - faktor apa saja yang menjadi berpengaruh terhadap kepuasan pengguna. Hal-hal tersebut diatas merupakan landasan pemikiran utama dari penelitian yang ingin dilakukan oleh peneliti.

\section{RUMUSAN PERMASALAHAN}

Permasalahan yang ingin diketahui adalah :

- Faktor-faktor apa saja yang berpengaruh signifikan terhadap tingkat kepuasan pemakai sistem informasi ?

- Apakah ada kesenjangan yang signifikan antara kinerja sistem informasi perkreditan dengan harapan pemakai sistem informasi

Dengan permasalahan tersebut diatas, maka peneliti mencoba untuk mencari faktor apa saja yang dapat mempengaruhi tingkat kepuasan pemakai dalam beberapa hal sebagai berikut :

1. Apakah informativeness berpengaruh signifikan terhadap tingkat kepuasan pemakai sistem informasi perkreditan

2. Apakah information format berpengaruh signifikan terhadap tingkat kepuasan pemakai sistem informasi perkreditan

3. Apakah easy of use berpengaruh signifikan terhadap tingkat kepuasan pemakai sistem informasi perkreditan 
4. Apakah timeliness berpengaruh signifikan terhadap tingkat kepuasan pemakai sistem informasi perkreditan

5. Apakah reliability berpengaruh signifikan terhadap tingkat kepuasan sistem informasi perkreditan

6. Apakah user background berpengaruh signifikan terhadap tingkat kepuasan pemakai sistem informasi perkreditan

7. Apakah ada kesenjangan antara kinerja dan harapan dari variable informativeness

8. Apakah ada kesenjangan antara kinerja dan harapan dari variable information format

9. Apakah ada kesenjangan antara kinerja dan harapan dari variable easy of use

10. Apakah ada kesenjangan antara kinerja dan harapan dari variable Timeliness

11. Apakah ada kesenjangan antara kinerja dan harapan dari variable Reliability

12. Apakah ada kesenjangan antara kinerja dan harapan dari variable User background

Dengan diketahui tingkat kepuasan diantara faktor-faktor kualitas layanan sistem informasi, maka ke depannya akan diambil langkahlangkah yang dibutuhkan untuk membuat sistem informasi yang sudah ada menjadi lebih baik lagi di masa depan.

\section{LANDASAN TEORI}

Menurut Information Technology Association of America (ITAA) (Url : www.wikipedia.com), teknologi informasi adalah "the study, design, development, implementation, support or management of computer-based information systems, particularly software applications and computer hardware." Menurut pengertian ini juga mengatakan bahwa teknologi informasi berkaitan dengan penggunaan computer elektronik dan perangkat lunak untuk mengubah, menyimpan, melindungi, memproses, mengirimkan, serta mengamankan informasi yang didapat.

Pada saat ini, penggunaan istilah teknologi informasi telah berkembang untuk mengartikan banyak instilah pada computer dan teknologi. Pengertian dari teknologu informasi menjadi sangat besar, dan memasuki pada banyak area. Para professional di bidang TI 
melakukan banyak variasi tugas mulai dari intall aplikasi sampai mendesain jaringan computer dan database informasi yang sangat rumit. Beberapa pekerjaan yang dilakukan oleh para professional TI bisa termasuk manajemen data, jaringan, hardware engineering, perangkat keras computer, database, desain perangkat lunak, serta manajemen dan administrasi semua system yang ada.

Kemajuan teknologi informasi yang pesat telah menjadikan teknologi informasi sebagai salah satu komponen utama dalam format perusahaan baru sebagai hasil (Richardus Eko Indrajit, 2000). Perkembangan teknologi informasi seperti local area network, wide area network, multimedia, data warehouse, intranet, dan internet telah membuat perusahaan mendefinisikan kembali visi dan misi bisnisnya, terutama yang berkaitan dengan strategi pelaksanaan bisnis.

Ada empat cara improvisasi yang dapat dilakukan terhadap prosesproses dalam perusahaan yang ditawarkan oleh teknologi informasi (Peppard, 1995) yaitu:

\section{Eliminate}

Menghilangkan proses-proses yang dianggap tidak perlu lagi dilakukan jika sistem komputer diimplementasikan, misalnya karena alasan efisiensi. Proses-proses seperti pengecekan secara manual terhadap kalkulasi-kalkulasi rumit yang tidak perlu lagi dilakukan setelah program berbasis spreadsheet dikembangkan merupakan salah satu contoh dari kemudahan yang ditawarkan teknologi informasi. Demikian pula dalam hal proses pembuatan laporan-laporan beragam, baik yang bersifat periodik maupun ad hoc yang biasanya memakan waktu berjam-jam jika harus dikerjakan secara manual, akan hilang dengan sendirinya karena diinstalasinya suatu laporan generator berbasis komputer.

\section{Simplified}

Penyederhanaan proses-proses tertentu atau pengurangan rantai proses untuk tujuan pelaksanaan aktifitas yang lebih cepat dan murah. Kasus klasik yang paling sering dilakukan oleh perusahaan adalah dengan melakukan simplifikasi terhadap formulir-formulir yang biasa dipergunakan untuk tujuan kontrol internal perusahaan (karena berdasarkan filosofi lama yang mengatakan bahwa semakin banyak SDM yang terlibat dalam melakukan kontrol terhadap suatu proses, akan semakin baik karena memperkecil kemungkinan terjadinya 
kolusi). Fasilitas komunikasi e-mail dan workflow yang ditawarkan pada konsep intranet merupakan salah satu alternatif yang paling efisien dan efektif untuk mempersingkat prosedur pengajuan dan persetujuan kredit di bank. Apalagi jika teknologi tersebut dilengkapi oleh sistem keamanan komputer yang canggih.

\section{Integrate}

Adalah berupa kemungkinan diintegrasikannya beberapa proses yang biasanya ditangani oleh beberapa karyawan dari berbagai divisi yang terpisah menjadi sebuah proses yang lebih sederhana. Dengan diimplementasikannya jaringan komputer berskala WAN, proses pengecekan barang di gudang yang biasanya harus melalui prosedur pada bagian logistik dapat dilakukan pula oleh seorang salesman sehingga dapat mencegah terjadinya overcommitted atau shortage terhadap pesanan pelanggan.

\section{Automate}

Adalah mengubah hal-hal yang biasanya dilakukan secara manual menjadi aktivitas mengunakan komputer.

Kegunaan informasi menurut Alter (1999, p132) terdiri dari :

- Information Quality : informasi yang baik berdasarkan pada akurasi, ketepatan, kelengkapan, tepat waktu dan personal atau organisasi yang membuat informasi tersebut.

- Information Accessibility : Kemudahan dalam mendapatkan dan memanipulasi informasi

- Information Presentation : Kesimpulan dan format yang dipresentasikan kepada pemakai.

- Penggunaan informasi yang dihasilkan oleh system informasi harus sesuai dengan kebutuhan pengguna, sehingga menimbulkan kepuasan bagi penerima informasi.

Informasi merupakan hal yang sangat penting dalam organisasi. Tanpa informasi maka akan menghambat kemajuan perusahaan. Kualitas informasi dihasilkan dari suatu system informasi yang berpengaruh penting pada persepsi pengguna system informasi mengenai kegunaan atau fungsi serta kemudahan dalam memakai system informasi tersebut. Menurut Webber (1999, p897) ukuran kualitas informasi dapat dilihat pada :

a. Authentivity, informasi itu harus otentik 
b. Accuracy, Berati informasi itu harus benar, tidak ada kesalahan dan tidak menyesatkan

c. Completeness, Informasi itu harus lengkap.

d. Uniqeness (No Redundancy), artinya informasi itu tidak dijelaskan secara berulang-ulang

e. Timeliness, artinya informasi itu tidak boleh terlambat diterima oleh penerima.

f. Relevance, informasi itu harus bermanfaat bagi pemakainya.

g. Comperhensibility, Informasi itu harus meliputi banyak hal disegala bidang secara lengkap

h. Precision, artinya informasi harus tepat memenuhi sasaran sesuai dengan kebutuhan.

i. Conciseness, informasi itu harus ringkas dan padat isinya

j. Informativeness, berarti informasi harus bersifat informatuf artinya jelas, tidak mengambang.

Menurut Bailey dan Pearson (1980) terdapat sembilan karakteristik kualitas informasi, adalah sebagai berikut :

a. Accuracy (ketepatan) - berhubungan dengan nilai atau angka informasi harus akurat

b. Precision (berhubungan dengan goal atau objectif yang telah di tentukan sebelumnya) - informasi harus tepat sasaran.

c. Nilai mata uang atau ukuran-ukuran financial - Informasi tidak harus mahal

d. Ketepatan waktu dari dihasilkannya keluaran atau output Informasi yang dihasilkan harus tepat waktu

e. Tingkat keandalan dari informasi tersebut - Informasi harus bias diandalkan

f. Kelengkapan dari informasi tersebut - Informasi harus lengkap

g. Ringkas - Informasi haru ringkas tapi padat

h. Bentuk dari informasi tersebut.

i. Tingkat relevansi dari informasi tersebut

Hal tersebut menjadi perhatian dalam riset terhadap pengguna informasi

Menurut Remenyi, Money dan Twite (1995, p119-121) ada dua pendekatan yang dipergunakan untuk mengukur kesenjangan kepuasan pemakai sisfo yang terdiri dari : 


\section{A. The Kim Model}

Merumuskan kepuasan pengguna dipengaruhi oleh kesenjangan antara harapan penggunaan sebelum implementasi dan pengalaman pengguna dalam menggunakan system, serta dipengaruhi oleh berbagai factor dalam organisasi.

B. The Miller-Doyle Approach

Mencoba merumuskan kepuasan pengguna dengan berusaha mengidentifikasi kebutuhan pengguna melalui derajat kepentingan yang ditentukan pengguna pada berbagai factor dari system informasi dengan menggunakan kuesioner. Selain itu model tersebut juga menilai kemampuan dan kinerja system informasi dari mata penggunanya.

Pada penelitian ini menggunakan pendekatan Miller-Doyle. Dimana kusioner dibagi menjadi 4 bagian (Remenyi, Twite, Money, 1995, p124) dimana bagian I berisi pertanyaan mengenai informasi karyawan seperti jenis kelamin dan jabatan. Bagian II berisi 31 pertanyaan mengenai berapa baik kinerja yang selama ini di dapat dengan skala pengukuran 1 = sangat tidak setuju dan $5=$ sangat setuju. Bagian III berisi seberapa besar harapan pemakai pada system yang ditawarkan dengan skala $1=$ sangat tidak puas dan $5=$ sangat puas. Dan bagian akhir, yaitu bagian IV berisi 5 pertanyaan yang mengukur kepuasan karyawan terhadap system informasi secara keseluruhan.

Menurut pandangan DR. Wirjono Prodjodikoro, SH, Koperasi adalah bersifat suatu kerjasama antara orang-orang yang termasuk golongan kurang mampu, yang ingin bersama untuk meringankan beban hidup atau beban kerja. (R.T Sutantya R.Hadikusua, S.H dan Dr. Sumantoro, hal 127 ).

Menurut Undang-Undang No.25 Tahun 1992 Koperasi adalah badan usaha yang beranggotakan orang-orang atau badan hukum koperasi dengan melandaskan kegiatannya berdasarkan prinsip koperasi sekaligus sebagai gerakan ekonomi rakyat yang berdasarkan asas kekeluargaan. Koperasi bertujuan untuk menyejahterakan anggotanya. Berdasarkan pengertian tersebut, yang dapat menjadi anggota koperasi yaitu: 
- Perorangan, yaitu orang yang secara sukarela menjadi anggota koperasi;

- Badan hukum koperasi, yaitu suatu koperasi yang menjadi anggota koperasi yang memiliki lingkup lebih luas.

\section{METODOLOGI PERANCANGAN}

Penelitian akan dimulai dari pengumpulan data adalah kuesioner yang berisi pertanyaan yang diajukan kepada responden untuk mengumpulkan informasi mengenai sistem informasi perkreditan. Pertanyaan-pertanyaan yang diajukan harus sesuai dengan apa yang akan dicapai dan sesuai dengan yang tercermin di dalam hipotesis. Pertanyaan-pertanyaan diabuat berdasarkan variable-variable yang mempengaruhi tingkat kepuasan pengguna sistem informasi seperti informativeness, information format, timeliness, easy of use, reliability, dan user background.

Penelitian dilakukan di Koperasi Perumahan Wanabakti Nusantasa (KPWN) yang beralamat di Gedung Manggala Wanabakti Blok 1 lantai $15 \mathrm{Jl}$. Jendral Gatot Subroto Jakarta-Pusat, penelitian akan dilakukan di serluruh divisi KPWN yang menggunakan sistem informasi perkreditan yang ada.

Waktu penelitian pada bulan Desember 2008 sampai dengan Januari 2009. pengumpulan data diperoleh dari populasi pengguna sistem informasi perkreditan KPWN di seluruh divisi yang akan dilakukan dengan pertanyaan melalui kuesioner.

Teknik pengumpulan data yang digunakan pada penelitian ini adalah dengan melakukan survey dan menyebarkan kuesioner kepada pemakai sistem informasi perkreditan, Teknik sampling yang digunakan adalah simple random sampling. Menurut Umar (2002, p92) kuesioner adalah suatu cara pengumpulan data dengan menyebarkan daftar pertanyaan kepada responden dengan harapan mereka akan memberikan respon terhadap daftar pertanyaan tersebut. Daftar pertanyaant ersebut bersifat terbuka jika jawaban tidak ditentukan sebelumnya dan bersifat tertutup jika alternative-alternatif 
jawaban telah disediakan. Instrument lembar daftar pertanyaan dpat berupa angket (kuesioner), checklist, ataupun skala.

Dalam penelitian ini terdapat 2 variabel, yaitu variable bebas (Xi) yang berupa kinerja sistem informasi perkreditan dan variable terikatnya (Y) berupa tingkat kepuasan pemakai dimana tingkat kepuasan tergantung pada semua aspek yang dimiliki oleh sistem informasi perkreditan tersebut dapat memnuhi kebutuhan pemakai atau tidak.

variable bebas adalah faktor-faktor sistem informasi perkreditan KPWN yang diukur dengan :

- Informativeness : mengukur apakah sistem infromasi menyediakan informasi yang sesuai dengan kebutuhan pemakai. komponen-komponen dari informativeness adalah sebagai berikut :

a. Sistem informasi yang dapat menydiakan informasi yang sesuai dengan kebutuhan operasional pemakai sisfo

b. Informasi yang dihasilkan oleh sistem informasi berguna bagi pemakai

c. Informasi yang akurat singkat, padat, jelas dan terinci

- Information format : mengukur apakah sistem informasi menyediakan format yang baik, komponen-komponen dari information format adalah sebagai berikut :

a. Informasi yang dikeluarkan mudah dibaca dan dimengerti

b. Output yang dihasilkan sesuai dengan kebutuhan pemakai

c. Menimbulkan satu persepsi bagi pemakai yang membaca hasil atau output dari sistem informasi

- $\quad$ Easy of use : mengukur informasi yang digunakan sangat mudah dilakukan oleh pemakai. komponen-komponen dari Easy of use adalah sebagai berikut :

a. User friendly

b. Mudah digunakan

c. Mudah dipelajari

d. Mudah dalam mengakses

- $\quad$ Timeliness : mengukur apakah sistem informasi yang tersedia yang memiliki ketepatan dan kecepatan waktu proses yang baik. komponen-komponen dari timeliness adalah sebagai berikut :

a. Informasi yang diterima selalu tepat waktu

b. Selalu menerima informasi terbaru 
c. Informasi yang cepat yang dapat mendukung pengambilan keputusan

- User background : mengukur apakah sistem informasi yang tersedia dipengaruhi oleh latar belakang formal maupun informal dari si pemakai. komponen-komponen user background yang akan digunakan dalam penelitian ini adalah sebagai berikut

a. Usia

b. Pengalaman Kerja

c. Latar Belakang Pendidikan Formal

d. Latar Belakang Jurusan Pendidikan

e. Pelatihan Sistem

f. Lama Penggunaan Komputer

- $\quad$ Reliability : mengukur apakah sistem informasi yang tersedia dapat diandalkan. komponen-komponen dari reliability adalah sebagai berikut :

a. Informasi yang dapat diandalkan

b. Informasi yang berguna sebagai pengambilan keputusan dan pemecahan masalah

c. Informasi yang dapat digunakan untuk membantu merancang strategi perusahaan

d. Informasi yang relevan dan terperinci

e. Informasi yang tidak mengambang, tidak berulang-ulang

f. Informasu yang sesuai dengan keadaan yang sebenarnya

Variabel terikat adalah kepuasan pemakai sistem informasi perkreditan Koperasi Perumahan Wanabakti Nusantara (KPWN)

Hipotesis yang dirumuskan dalam penelitian ini adalah hubungan antara berbagai faktor dan tentang kesenjangan untuk berbagai kualitas system informasi terhadap tingkat kepuasan pengguna system informasi.

Hipotesis mengenai kesenjangan berbagai faktor, adalah :

1. Ada kesenjangan yang signifikan antara harapan dengan kinerja untuk faktor informativeness.

2. Ada kesenjangan yang signifikan antara harapan dengan kinerja untuk faktor information format.

3. Ada kesenjangan yang signifikan antara harapan dengan kinerja untuk faktor easy of use. 
4. Ada kesenjangan yang signifikan antara harapan dengan kinerja untuk faktor timeliness.

5. Ada kesenjangan yang signifikan antara harapan dengan kinerja untuk faktor reliability.

Hipotesis untuk analisis regresi, adalah :

6. Ada pengaruh signifikan antara informativeness sistem informasi perkreditan KPWN dengan kepuasan pemakai.

7. Ada pengaruh signifikan antara information format sistem informasi perkreditan KPWN dengan kepuasan pemakai.

8. Ada pengaruh signifikan antara easy of use sistem informasi perkreditan KPWN dengan kepuasan pemakai.

9. Ada pengaruh signifikan antara timeliness sistem informasi perkreditan KPWN dengan kepuasan pemakai.

10. Ada pengaruh signifikan antara reliability sistem informasi perkreditan KPWN dengan kepuasan pemakai.

Hipotesis untuk analisis Chi-Square, adalah :

11. Ada pengaruh signifikan antara Usia pengguna sistem informasi perkreditan KPWN dengan kepuasan pemakai.

12. Ada pengaruh signifikan antara Pengalaman Kerja pengguna sistem informasi perkreditan KPWN dengan kepuasan pemakai.

13. Ada pengaruh signifikan antara Latar Belakang Pendidikan Formal pengguna sistem informasi perkreditan KPWN dengan kepuasan pemakai.

14. Ada pengaruh signifikan antara Latar Belakang Jurusan Pendidikan pengguna sistem informasi perkreditan KPWN dengan kepuasan pemakai.

15. Ada pengaruh signifikan antara Pelatihan pengguna sistem informasi perkreditan KPWN dengan kepuasan pemakai.

16. Ada pengaruh signifikan antara Penggunaan komputer dengan kepuasan pemakai.

\section{HASIL}

Bab ini akan membahas dan menganalisa hasil dari penelitian yang telah didapatkan. Hasilnya mencakup penelitian data primer yang diperoleh dari kuesioner yang di distribusikan kepada seluruh 
pengguna sistem informasi. Responden diambil dari kantor KPWN tepatnya di seluruh divisi yang berada di blok I lantai 15 Gedung Manggala Wanabakti Jalan Jendral Gatot Subroto, Jakarta Pusat.

Karakteristik Responden yang diambil adalah Jenis Kelamin, Jabatan, Usia, Pengalaman Kerja, Latar belakang pendidikan formal, Jurusan pendidikan, Pelatihan SI KPWN, dan Lama menggunakan komputer.

Dari 32 responden yang terdiri dari staff dan kepala divisi di KPWN, didapatkan 65,6\% responden atau sebanyak 21 orang adalah laki-laki sedangkan $34,4 \%$ responden atau sebanyak 11 orang adalah perempuan.

Dilihat dari jabatan pengguna sistem informasi, dari 32 responden 15,6\% atau sebanyak 5 orang merupakan kepala divisi sedangkan mayoritas pengguna berada pada level staff sebesar 84,4\% atau sebanyak 27 orang. Sedangkan untuk jajaran pengurus tidak menjalankan fungsi operasional sehingga tidak menggunakan sistem sama sekali.

Untuk usia pengguna sistem informasi di KPWN responden yang berumur 50 tahun keatas sebesar 3,1\% atau sebanyak 1 orang, untuk responden yang berumur 40-49 tahun sebesar 15,6\% atau sebanyak 5 orang, untuk resonden yang berumur 30-39 tahun sebesar 34,4\% atau sebanyak 11 orang, dan mayoritas berada pada kisaran umur 20-29 tahun sebesar 46,9\% atau sebanyak 15 orang.

Untuk pengalaman kerja di KPWN, responden yang mempunyai pengalaman 5 tahun atau lebih terdiri dari 31,3\% atau sebanyak 10 orang, untuk pengalaman yang berkisar 1-2 tahun adalah 9,4\% atau sebanyak 3 orang, untuk pengalaman 3-4 tahun adalah 46,9\% atau sebanyak 15 orang, dan terakhir yang bekerja kurang dari 1 tahun sebesar $12,5 \%$ atau sebanyak 4 orang.

Untuk latar belakang pendidikan formal, mayoritas responden berasal dari pendidikan formal strata-1 yaitu sebesar 87,5\% atau sebanyak 28 orang. Sedangkan sisanya berpendidikan formal diploma yaitu sebesar $12,5 \%$ atau sebanyak 4 orang. 
Untuk latar belakang Jurusan, mayoritas responden berasal dari jurusan Non-Sistem informasi / Komputer yaitu sebesar 87,5\% atau sebanyak 28 orang sedangkan sisanya sebesar 12,5\% atau sebanyak 4 orang merupakan responden yang berlatar belakang jurusan sistem informasi / computer

Untuk pelatihan sistem Informasi KPWN, sebesar 81,3\% responden atau sebanyak 26 orang menjawab bahwa mereka pernah mendapatkan pelatihan sistem informasi KPWN yang saat itu dilaksanakan di kantor cabang KPWN yang berada di daerah Bogor, Jawa Barat. Sedangkan sisanya sebesar 18,8\% atau sebanyak 6 orang belum mendapatkan pelatihan Sistem Informasi Tersebut sehingga pelatihan singkat hanya didapatkan ketika akan menggunakan sistem saat operasional harian.

Untuk lamanya penggunaan komputer, responden mempunyai pengalaman yang cukup tinggi untuk penggunaan komputer. Hal ini dapat dilihat dimana mayoritas responden yang mempunyai pengalaman lebih dari 5 tahun dalam menggunakan komputer sebesar $71,9 \%$ atau sebanyak 23 orang sedangkan sisanya $28,1 \%$ atau sebanyak 9 orang mempunyai pengalaman selama 4 tahun.

Pada tabel dibawah ini akan dibahas mengenai validitas dan reliablitas dari pertanyaan-pertanyaan yang diajukan pada kuesioner kinerja sistem informasi KPWN, diharapkan dengan analisis ini akan didapatkan pertanyaan-pertanyaan yang valid dan reliable untuk digunakan dalam analisis selanjutnya.

Tabel 1. Validitas Item Untuk Kinerja Aspek Informativeness

\begin{tabular}{|r|r|}
\hline $\begin{array}{c}\text { Cronbach's } \\
\text { Alpha }\end{array}$ & N of Items \\
\hline .854 & 5 \\
\hline
\end{tabular}

\begin{tabular}{|l|r|r|r|r|c|}
\hline & $\begin{array}{c}\text { Scale } \\
\text { Mean if } \\
\text { Item } \\
\text { Deleted }\end{array}$ & $\begin{array}{c}\text { Scale } \\
\text { Variance } \\
\text { if Item } \\
\text { Deleted }\end{array}$ & $\begin{array}{c}\text { Corrected } \\
\text { Item-Total } \\
\text { Correlation }\end{array}$ & $\begin{array}{c}\text { Cronbach's } \\
\text { Alpha if } \\
\text { Item } \\
\text { Deleted }\end{array}$ & Validitas \\
\hline B.Informativeness.1 & 15.22 & 6.564 & .558 & .850 & Valid \\
B.Informativeness.2 & 15.28 & 6.080 & .613 & .837 & Valid \\
B.Informativeness.3 & 15.41 & 5.346 & .734 & .806 & Valid \\
B.Informativeness.4 & 15.31 & 5.706 & .662 & .825 & Valid \\
B.Informativeness.5 & 15.41 & 5.217 & .778 & .793 & Valid \\
\hline
\end{tabular}


Untuk pertanyaan dalam kuesioner kinerja sistem informasi KPWN dari aspek informativeness, maka didapatkan bahwa semua pertanyaan adalah valid.

Tabel 2. Validitas Item Untuk Kinerja Aspek Information Format

\begin{tabular}{|r|r|}
\hline $\begin{array}{c}\text { Cronbach's } \\
\text { Alpha }\end{array}$ & N of Items \\
\hline .810 & 5 \\
\hline
\end{tabular}

\begin{tabular}{|l|r|r|r|r|c|}
\hline & $\begin{array}{c}\text { Scale } \\
\text { Mean if } \\
\text { Item } \\
\text { Deleted }\end{array}$ & $\begin{array}{c}\text { Scale } \\
\text { Variance } \\
\text { if Item } \\
\text { Deleted }\end{array}$ & $\begin{array}{c}\text { Corrected } \\
\text { Item-Total } \\
\text { Correlation }\end{array}$ & $\begin{array}{c}\text { Cronbach's } \\
\text { Alpha if } \\
\text { Item } \\
\text { Deleted }\end{array}$ & Validitas \\
\hline B.Information Format 1 & 15.06 & 7.028 & .565 & .782 & Valid \\
B.Information Format 2 & 15.06 & 7.673 & .520 & .795 & Valid \\
B.Information Format 3 & 15.03 & 6.096 & .745 & .723 & Valid \\
B.Information Format 4 & 15.09 & 6.733 & .596 & .773 & Valid \\
B.Information Format 5 & 14.88 & 7.016 & .564 & .783 & Valid \\
\hline
\end{tabular}

Untuk pertanyaan dalam kuesioner kinerja sistem informasi KPWN dari aspek information format, maka didapati bahwa semua pertanyaan yang diajukan dalam kuesioner adalah valid

Tabel 3. Validitas Item Untuk Kinerja Aspek Easy of Use

\begin{tabular}{|r|r|}
\hline $\begin{array}{c}\text { Cronbach's } \\
\text { Alpha }\end{array}$ & N of Items \\
\hline .806 & 6 \\
\hline
\end{tabular}

\begin{tabular}{|l|r|r|r|r|c|}
\hline & $\begin{array}{c}\text { Scale } \\
\text { Mean if } \\
\text { Item } \\
\text { Deleted }\end{array}$ & $\begin{array}{c}\text { Scale } \\
\text { Variance } \\
\text { if Item } \\
\text { Deleted }\end{array}$ & $\begin{array}{c}\text { Corrected } \\
\text { Item-Total } \\
\text { Correlation }\end{array}$ & $\begin{array}{c}\text { Cronbach's } \\
\text { Alpha if } \\
\text { Item } \\
\text { Deleted }\end{array}$ & Validitas \\
\hline B.Easy of Use 1 & 19.91 & 5.894 & .415 & .809 & Valid \\
B.Easy of Use 2 & 19.94 & 5.415 & .698 & .748 & Valid \\
B.Easy of Use 3 & 19.84 & 5.426 & .744 & .741 & Valid \\
B.Easy of Use 4 & 19.88 & 5.532 & .575 & .773 & Valid \\
B.Easy of Use 5 & 19.97 & 5.386 & .543 & .782 & Valid \\
B.Easy of Use 6 & 20.00 & 5.677 & .472 & .798 & Valid \\
\hline
\end{tabular}


Untuk pertanyaan dalam kuesioner kinerja sistem informasi KPWN dari aspek Easy of Use, maka didapati bahwa semua pertanyaan yang diajukan dalam kuesioner adalah valid.

Tabel 4. Validitas Item Untuk Kinerja Aspek Timeliness

\begin{tabular}{|r|r|}
\hline $\begin{array}{c}\text { Cronbach's } \\
\text { Alpha }\end{array}$ & N of Items \\
\hline .711 & 5 \\
\hline
\end{tabular}

\begin{tabular}{|l|r|r|r|r|c|}
\hline & $\begin{array}{c}\text { Scale } \\
\text { Mean if } \\
\text { Item } \\
\text { Deleted }\end{array}$ & $\begin{array}{c}\text { Scale } \\
\text { Variance } \\
\text { if Item } \\
\text { Deleted }\end{array}$ & $\begin{array}{c}\text { Corrected } \\
\text { Item-Total } \\
\text { Correlation }\end{array}$ & $\begin{array}{c}\text { Cronbach's } \\
\text { Alpha if Item } \\
\text { Deleted }\end{array}$ & Validitas \\
\hline B.Timeliness 1 & 14.78 & 3.209 & .576 & .613 & Valid \\
B.Timeliness 2 & 14.66 & 3.072 & .624 & .588 & Valid \\
B.Timeliness 3 & 14.72 & 3.757 & .521 & .643 & Valid \\
B.Timeliness 4 & 14.59 & 4.314 & .394 & .692 & Valid \\
B.Timeliness 5 & 14.88 & 4.435 & .250 & .739 & Tidak Valid \\
\hline
\end{tabular}

Untuk pertanyaan dalam kuesioner kinerja sistem informasi KPWN dari aspek Timeliness, maka didapati bahwa pertanyaan no.5 : "Penyedia layanan sistem informasi melaksanakan janji serta kesanggupan dengan baik” adalah tidak Valid.

Tabel 5. Validitas Item Untuk Kinerja Aspek Reliability

\begin{tabular}{|r|r|}
\hline $\begin{array}{c}\text { Cron } \\
\text { bach's Alpha }\end{array}$ & N of Items \\
\hline .857 & 9 \\
\hline
\end{tabular}

\begin{tabular}{|l|c|c|r|r|c|}
\hline & $\begin{array}{c}\text { Scale } \\
\text { Mean if } \\
\text { Item } \\
\text { Deleted }\end{array}$ & $\begin{array}{c}\text { Scale } \\
\text { Variance } \\
\text { if Item } \\
\text { Deleted }\end{array}$ & $\begin{array}{c}\text { Corrected } \\
\text { Item-Total } \\
\text { Correlation }\end{array}$ & $\begin{array}{c}\text { Cronbach's } \\
\text { Alpha if Item } \\
\text { Deleted }\end{array}$ & Validitas \\
\hline B.Reliability 1 & 29.19 & 18.738 & .414 & .860 & Valid \\
B.Reliability 2 & 29.44 & 19.222 & .434 & .856 & Valid \\
B.Reliability 3 & 29.50 & 18.129 & .553 & .845 & Valid \\
B.Reliability 4 & 29.06 & 19.222 & .576 & .845 & Valid \\
B.Reliability 5 & 29.16 & 17.362 & .676 & .833 & Valid \\
B.Reliability 6 & 29.00 & 16.065 & .735 & .825 & Valid \\
B.Reliability 7 & 29.09 & 17.055 & .700 & .830 & Valid \\
B.Reliability 8 & 29.00 & 18.323 & .562 & .844 & Valid \\
B.Reliability 9 & 29.06 & 18.125 & .617 & .839 & Valid \\
\hline
\end{tabular}

Fajriyansyah S, M. \& Edi A/Journal of Applied Finance and Accounting,4(2),167-193 (183 
Untuk pertanyaan dalam kuesioner kinerja sistem informasi KPWN dari aspek Reliability, maka didapati bahwa semua pertanyaan yang diajukan dalam kuesioner adalah valid.

Berdasarkan analisis validitas dan reliabilitas diatas, maka dari 30 pertanyaan yang diajukan dalam kuesioner pengukuran kinerja aspek informativeness, information format, Easy of Use, Timeliness, dan Reliability maka didapatkan 29 pertanyaan yang valid

Pada tabel dibawah ini akan dibahas mengenai validitas dan reliablitas dari pertanyaan-pertanyaan yang diajukan pada kuesioner harapan sistem informasi KPWN, diharapkan dengan analisis ini akan didapatkan pertanyaan-pertanyaan yang valid dan reliable untuk digunakan dalam analisis selanjutnya.

Tabel 6. Validitas Untuk Item Harapan Aspek Informativeness

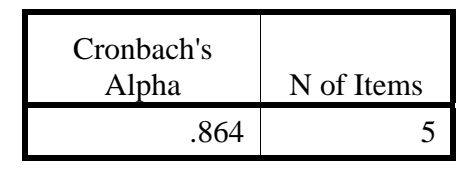

\begin{tabular}{|l|r|r|r|r|c|}
\hline & $\begin{array}{c}\text { Scale } \\
\text { Mean if } \\
\text { Item } \\
\text { Deleted }\end{array}$ & $\begin{array}{c}\text { Scale } \\
\text { Variance if } \\
\text { Item } \\
\text { Deleted }\end{array}$ & $\begin{array}{c}\text { Corrected } \\
\text { Item-Total } \\
\text { Correlation }\end{array}$ & $\begin{array}{c}\text { Cronbach's } \\
\text { Alpha if } \\
\text { Item } \\
\text { Deleted }\end{array}$ & Validitas \\
\hline C.Informativeness 1 & 16.72 & 6.144 & .676 & .837 & Valid \\
C.Informativeness 2 & 16.75 & 6.581 & .554 & .866 & Valid \\
C.Informativeness 3 & 16.75 & 5.935 & .763 & .816 & Valid \\
C.Informativeness 4 & 16.75 & 5.871 & .785 & .810 & Valid \\
C.Informativeness 5 & 16.78 & 5.983 & .655 & .844 & Valid \\
\hline
\end{tabular}

Untuk pertanyaan dalam kuesioner harapan dari sistem informasi KPWN berdasarkan aspek informativeness, maka didapatkan bahwa semua pertanyaan yang diajukan adalah valid.

Tabel 7. Validitas Untuk Item Harapan Aspek Information Format

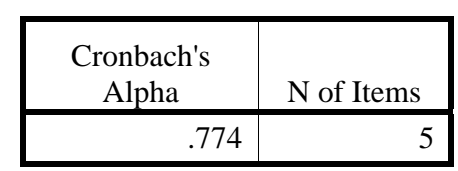




\begin{tabular}{|l|r|r|r|r|r|}
\hline & $\begin{array}{c}\text { Scale } \\
\text { Mean if } \\
\text { Item } \\
\text { Deleted }\end{array}$ & $\begin{array}{c}\text { Scale } \\
\text { Varianc } \\
\text { e if Item } \\
\text { Deleted }\end{array}$ & $\begin{array}{c}\text { Corrected } \\
\text { Item-Total } \\
\text { Correlation }\end{array}$ & $\begin{array}{c}\text { Cronbach } \\
\text { 's Alpha } \\
\text { if Item } \\
\text { Deleted }\end{array}$ & Validitas \\
\hline C.Information Format 1 & 16.78 & 3.596 & .583 & .724 & Valid \\
C.Information Format 2 & 16.53 & 4.644 & .467 & .759 & Valid \\
C.Information Format 3 & 16.78 & 3.402 & .665 & .689 & Valid \\
C.Information Format 4 & 16.69 & 4.480 & .426 & .770 & Valid \\
C.Information Format 5 & 16.59 & 4.184 & .646 & .708 & Valid \\
\hline
\end{tabular}

Untuk pertanyaan dalam kuesioner harapan dari sistem informasi KPWN berdasarkan aspek information format, maka didapatkan bahwa semua pertanyaan yang diajukan adalah valid.

Tabel 8. Validitas Untuk Item Harapan Aspek Easy of Use

\begin{tabular}{|r|r|}
\hline $\begin{array}{c}\text { Cronbach's } \\
\text { Alpha }\end{array}$ & N of Items \\
\hline .796 & 6 \\
\hline
\end{tabular}

\begin{tabular}{|l|r|r|r|r|c|}
\hline & $\begin{array}{c}\text { Scale } \\
\text { Mean if } \\
\text { Item } \\
\text { Deleted }\end{array}$ & $\begin{array}{c}\text { Scale } \\
\text { Variance } \\
\text { if Item } \\
\text { Deleted }\end{array}$ & $\begin{array}{c}\text { Corrected } \\
\text { Item-Total } \\
\text { Correlation }\end{array}$ & $\begin{array}{c}\text { Cronbach's } \\
\text { Alpha if } \\
\text { Item } \\
\text { Deleted }\end{array}$ & Validitas \\
\hline C.Easy of Use 1 & 21.47 & 4.128 & .451 & .792 & Valid \\
C.Easy of Use 2 & 21.44 & 4.190 & .659 & .744 & Valid \\
C.Easy of Use 3 & 21.47 & 3.741 & .713 & .723 & Valid \\
C.Easy of Use 4 & 21.47 & 3.934 & .709 & .728 & Valid \\
C.Easy of Use 5 & 21.56 & 4.319 & .479 & .780 & Valid \\
C.Easy of Use 6 & 21.50 & 4.516 & .353 & .810 & Valid \\
\hline
\end{tabular}

Untuk pertanyaan dalam kuesioner harapan dari sistem informasi KPWN berdasarkan aspek information format, maka didapatkan bahwa semua pertanyaan yang diajukan adalah valid.

Tabel 9. Validitas Untuk Item Harapan Aspek Timeliness

\begin{tabular}{|r|r|}
\hline $\begin{array}{c}\text { Cronbach's } \\
\text { Alpha }\end{array}$ & N of Items \\
\hline .830 & 5 \\
\hline
\end{tabular}




\begin{tabular}{|l|c|c|r|r|c|}
\hline & $\begin{array}{c}\text { Scale } \\
\text { Mean if } \\
\text { Item } \\
\text { Deleted }\end{array}$ & $\begin{array}{c}\text { Scale } \\
\text { Variance if } \\
\text { Item } \\
\text { Deleted }\end{array}$ & $\begin{array}{c}\text { Corrected } \\
\text { Item-Total } \\
\text { Correlation }\end{array}$ & $\begin{array}{c}\text { Cronbach's } \\
\text { Alpha if } \\
\text { Item } \\
\text { Deleted }\end{array}$ & Validitas \\
\hline C.Timeliness 1 & 16.41 & 3.668 & .697 & .775 & Valid \\
C.Timeliness 2 & 16.44 & 3.931 & .594 & .805 & Valid \\
C.Timeliness 3 & 16.47 & 3.870 & .658 & .788 & Valid \\
C.Timeliness 4 & 16.50 & 3.484 & .723 & .766 & Valid \\
C.Timeliness 5 & 16.44 & 4.190 & .472 & .837 & Valid \\
\hline
\end{tabular}

Untuk pertanyaan dalam kuesioner harapan dari sistem informasi KPWN berdasarkan aspek Timeliness, maka didapatkan bahwa semua pertanyaan yang diajukan adalah valid.

Tabel 10. Validitas Untuk Item Harapan Aspek Reliability

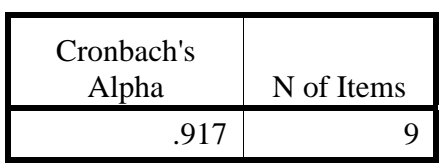

\begin{tabular}{|l|r|r|r|r|c|}
\hline & $\begin{array}{c}\text { Scale } \\
\text { Mean if } \\
\text { Item } \\
\text { Deleted }\end{array}$ & $\begin{array}{c}\text { Scale } \\
\text { Variance } \\
\text { if Item } \\
\text { Deleted }\end{array}$ & $\begin{array}{c}\text { Corrected } \\
\text { Item-Total } \\
\text { Correlation }\end{array}$ & $\begin{array}{c}\text { Cronbach's } \\
\text { Alpha if Item } \\
\text { Deleted }\end{array}$ & Validitas \\
\hline C.Reliability 1 & 32.78 & 27.854 & .564 & .916 & Valid \\
C.Reliability 2 & 32.91 & 24.926 & .723 & .907 & Valid \\
C.Reliability 3 & 32.97 & 24.483 & .785 & .902 & Valid \\
C.Reliability 4 & 32.56 & 25.738 & .788 & .902 & Valid \\
C.Reliability 5 & 32.69 & 26.028 & .677 & .910 & Valid \\
C.Reliability 6 & 32.75 & 26.065 & .746 & .905 & Valid \\
C.Reliability 7 & 32.69 & 26.415 & .706 & .907 & Valid \\
C.Reliability 8 & 32.56 & 27.028 & .704 & .908 & Valid \\
C.Reliability 9 & 32.59 & 27.152 & .700 & .908 & Valid \\
\hline
\end{tabular}

Untuk pertanyaan dalam kuesioner harapan dari sistem informasi KPWN berdasarkan aspek Reliability, maka didapatkan bahwa semua pertanyaan yang diajukan adalah valid.

Berdasarkan analisis validitas dan reliabilitas diatas, maka dari 30 pertanyaan yang diajukan dalam kuesioner pengukuran harapan aspek informativeness, information format, Easy of Use, Timeliness, dan 
Reliability maka didapatkan bahwa semua pertanyaan yang diajukan adalah valid

Mengenai besaran kesenjangan dari semua aspek yang telah diurutkan dari nilai terbesar sampai dengan terkecil dapat dilihat pada table seperti dibawah ini :

Tabel 11. Besaran Kesenjangan Berdasarkan Nilai Terbesar

\begin{tabular}{|l|c|c|}
\hline \multicolumn{1}{|c|}{ Aspek } & Kesenjangan (Gap) & P-Value \\
\hline 1. Reliability & .4444 & .001 \\
2. Information Format & .4125 & .002 \\
3. Timeliness & .3937 & .001 \\
4. Informativeness & .3563 & .009 \\
5. Easy of Use & .3125 & .002 \\
\hline
\end{tabular}

Dari keseluruhan analisis kesenjangan kinerja dan harapan dari semua aspek diatas, maka dapat disimpulkan bahwa masih terdapat kesenjangan yang signifikan pada semua aspek yang ada. Aspek yang ada yang kinerjanya sudah memenuhi harapan pengguna yaitu aspek Easy of Use, dan Informativeness. Yang belum memenuhi harapan pengguna adalah Information Format, sedangkan untuk Timeliness dan Reliability termasuk aspek yang tidak terlalu diharapkan pengguna dan kinerjanya pun belum baik.

Secara keseluruhan, perlu dilakukan peningkatan pada aspek-aspek yang ada dengan diberikan skala prioritas aspek mana yang perlu dibenahi berdasarkan letak kuadran grafik kartesius. Aspek yang perlu dibenahi berdasarkan skala prioritas adalah aspek Information Format (Kuadran A), Easy of Use (Kuadran B), Informativeness (Kuadran B), Timeliness (Kuadran C), dan Reliability (Kuadran C).

Kesimpulan untuk hipotesis yang telah dibuat mengenai pengaruh variabel-variabel yang ada terhadap kepuasan pengguna sistem informasi perkreditan di KPWN dapat dilihat seperti pada table dibawah ini : 
Tabel 12. Ringkasan Analisis Regresi Linier

\begin{tabular}{|l|c|c|}
\hline \multicolumn{1}{|c|}{ Aspek } & $\mathrm{P}-$ Value & Keterangan \\
\hline 1. Informativeness & .378 & Tidak Signifikan \\
2. Information Format & .120 & Tidak Signifikan \\
3. Easy of Use & .692 & Tidak Signifikan \\
4. Timeliness & .704 & Tidak Signifikan \\
5. Reliability & .035 & Signifikan \\
\hline
\end{tabular}

H6 : Ada pengaruh signifikan antara informativeness sistem informasi perkreditan KPWN dengan kepuasan pemakai. $\rightarrow$ Ditolak H7 : Ada pengaruh signifikan antara information format sistem informasi perkreditan KPWN dengan kepuasan pemakai. $\rightarrow$ Ditolak H8 : Ada pengaruh signifikan antara easy of use sistem informasi perkreditan KPWN dengan kepuasan pemakai. $\rightarrow$ Ditolak H9 : Ada pengaruh signifikan antara Timeliness sistem informasi perkreditan KPWN dengan kepuasan pemakai. $\rightarrow$ Ditolak

H10 : Ada pengaruh signifikan antara Reliability sistem informasi perkreditan KPWN dengan kepuasan pemakai. $\rightarrow$ Diterima

Dari hasil perhitungan diatas, dapat terlihat bahwa aspek yang paling berpengaruh signifikan terhadap kepuasan pengguna sistem informasi perkreditan di KPWN ada pada aspek reliability, sedangkan untuk aspek-aspek yang lain ternyata tidak berpengaruh secara signifikan terhadap kepuasaan pengguna.

Hal ini menunjukkan bahwa sistem yang ada harus dapat memperhatikan aspek yang terdapat pada Reliabilitas sistem informasi, seperti penyediaaan data dan informasi yang dapat diandalakan dan dipercaya serta sistem yang stabil dan tidak mudah mengalami kerusakan sehingga dapat digunakan dengan baik oleh para pengguna sistem informasi perkreditan di KPWN.

Untuk analisis chi-square yang mengukur signifikansi hubungan antara faktor-faktor user background dengan kepuasan pengguna, dapat dilihat pada table berikut. 
Tabel 13. Ringkasan Faktor-faktor untuk kepuasan

\begin{tabular}{|l|c|c|}
\hline \multicolumn{1}{|c|}{ Faktor } & P-Value & Kesimpulan \\
\hline Usia & .890 & Tidak Signifikan \\
Pengalaman kerja & .796 & Tidak Signifikan \\
Latar Belakang Pendidikan & .002 & Signifikan \\
Latar Belakang Jurusan & .394 & Tidak Signifikan \\
Pelatihan Sistem Informasi & .267 & Tidak Signifikan \\
Lama Penggunaan Komputer & .789 & Tidak Signifikan \\
\hline
\end{tabular}

Dari kesemua faktor-faktor diatas, yang mempunyai hubungan signifikan dengan kepuasaan pengguna sistem informasi KPWN hanya latar belakang pendidikan

Kesimpulan yang dapat diambil dari hasil perhitungan diatas bahwa latar belakang pendidikan mempunyai pengaruh yang signifikan karena karyawan dengan latar belakang pendidikan yang berbeda kemungkinan mempunyai ketertarikan untuk mengimplementasikan keahlian dan pendidikan yang didapat kepada perusahaan tempat mereka bekerja secara lebih baik.

Hal ini menggambarkan bahwa karakteristik pengguna mempunyai pengaruh terhadap kepuasaan. namun dalam penelitian ini, tidak semua faktor karakateristik berpengaruh terhadap kepuasan karyawan.

Dalam penelitian mengenai hubungan karakteristik dengan kepuasaan pengguna memang mempunyai hasil yang bervariasi. Hal ini sesuai dengan studi kelayakan yang pernah dilakukan oleh Kalleberg (1977), Lee dan Wibur (1985), dan Martin dan Hanson (1985) yang mengatakan bahwa karakteristik karyawan seperti usia, latar belakang pendidikan, pengalaman kerja berpengaruh terhadap kepuasan kerja karyawan. Sedangkan menurut Reudavery (2001) menyatakan bahwa tidak ada hubungan yang signifikan antara umur atau level pendidikan karyawan atau karakteristik lama bekerja di perusahaan dinyatakan tidak ada hubungan signifikan dengan kepuasan karyawan (O'Reilly dan Roberts, 1975 ; Bodein et all, 1992 dikutip dari Dickie et al) 


\section{KESIMPULAN}

Dari analisis yang sudah dilakukan pada bab-bab sebelumnya, maka dapat ditarik kesimpulan sebagai berikut :

1. Secara keseluruhan semua aspek ada perbedaan yang signifikan antara harapan dan kinerja. Hal ini menunjukkan bahwa pengguna system informasi tidak merasa puas terhadap ke 5 aspek tersebut.

2. Dari keseluruhan aspek tersebut, urutan kesenjangan adalah sebagai berikut dimulai dari kesenjangan paling besar yaitu pada aspek Reliability, Information Format, Timeliness, Informativeness, dan Easy of Use.

3. Dari analisis regresi, dapat disimpulkan bahwa hanya variabel Reliabillity, yang berpengaruh signifikan terhadap kepuasan pengguna.

4. Dari analisis chi-square terhadap faktor-faktor user background, hanya latar belakang pendidikan yang berpengaruh signifikan terhadap kepuasan pengguna.

\section{DAFTAR ACUAN}

Asian, Olivia. 2005, Analisis Kepuasan Karyawan terhadap Layanan Situs Web Direktorat Jenderal Bina Produksi Hortikultura Departemen Pertanian (Studi Kasus: Situs Web Hortikultura), Tesis S2 Universitas Bina Nusantara, Jakarta.

Jatimurti, Domas, 2003, Analisis kepuasan pemakai system informasi layanan pelanggan pada perusahaan telekomunikasi selular (Studi Kasus : PT. Satelindo), Tesis S2 Univ. Bina Nusantara, Jakarta.

Saleh, Nasimullah. 1999, Jarkomp : Model dan Analisis, Skripsi S1 Universitas Negeri Jakarta, Jakarta.

Setiabudi, Haris, et.al. 2005. Analisis Kepuasan Pemakai "Kios Informasi" (http://student.binus.ac.id) Studi Kasus Univ. Bina Nusantara , Tesis S2 Universitas Bina Nusantara, Jakarta. 
Siehoyono, Lintje. 2006. Analisa Hubungan Latar Belakang Karyawan dan Pengaruh Kualitas Layanan Internal Terhadap Kepuasn Karyawan Hotel X, Surabaya. [Online Available : http://www.petra.ac.id/ puslit/journals/dir.php?DepartmentID= HOT ] [2009, Feb 2]

Stefanus, Thomas. 2008. Analisa Kesenjangan Kualitas Pelayanana dan Kepuasan Konsumen Pengunjung Plaza Tunjungan Surabaya. [ Online Available : http://www.petra.ac.id/ puslit/journals/dir.php?DepartmentID= MAN ] [2009, Feb 2]

Terkelin, Yohannes. 2008, Analisis Elemen-Elemen Ekuitas Merek Dari Sepeda Motor, Tesis S2 Univ.Bina Nusantara, Jakarta.

Trihendardi, Cornelius. 2006, Langkah Mudah Menguasai Statistik Menggunakan SPSS 15, Andipublisher, Yogyakarta.

\section{DAFTAR PUSTAKA}

Alter, Stevensen , 1999, Information System : A Management Perspective, $3^{\text {rd }}$ Ed., Addison Wesley, New Jersey.

Bailey, J., \& Pearson, S. (1983). Development of a Tool for Measuring and Analyzing Computer User Satisfaction. Management Science, 29(5), 530-545.

Chin, J., Diehl, V., \& Norman, L. (1988). Development of an instrument measuring user satisfaction of the human-computer interface. Paper presented at the Proceedings of the SIGCHI conference on Human factors in computing systems, New York.

Childers, T. L., Carr, C. L., Peck, J., \& Carson, S. (2001). Hedonic and utilitarian motivations for online retail shopping behavior. Journal of Retailing, 77, 511-535.

Crosby, L. A., \& Stephens, N. (1987). Effects of relationship marketing on satisfaction, retention, and prices in the life insurance industry. Journal of Marketing Research, 24, 404411. 
Davenport, Thomas H, 1993, Process Innovation, Reengineering Work Through Information Technology, Harvard Business School Press.

DeLone, W., \& McLean, E. R. (2004). Measuring e-commerce success: Applying the DeLone \& McLean information systems success model. International Journal of Electronic Commerce, 9(1), 31-47.

Elliot, S., \& Fowell, S. (2000). Expectations versus reality: A snapshot of consumer experiences with Internet retailing. International Journal of Information Management, 20, 323336.

Gefen, D. (2000). E-commerce: The role of familiarity and trust.Omega, 28(6), 725-737.

Hiltunen, M., Laukka, M., \& Luomala, J. (2002). Mobile User Experience. Helsinki: IT Press.

Hong, W., Thong, J. Y. L., \& Tam, K. Y. (2005). The effects of information format and

shopping task on consumers' online shopping behavior: A cognitive fit perspective. Journal of Management Information Systems, 21(3), 149-184.

Indrajit, Richardus E, 2000, Manajemen Sistem Informasi dan Teknologi Informasi, PT Elex Media Komputindo Jakarta.

Ives, B., Olson, M., \& Baroudi, J. (1983). The Measurement of User Information Satisfaction. Communications of the ACM, 26, 785-793.

Jones, M. A., \& Suh, J. (2000). Transaction- specific satisfaction and overall satisfaction: An empirical analysis. Journal of Services Marketing, 14(2), 147-159.

Lindgaard, G., \& Dudek, C. (2003). What is this evasive beast we call user satisfaction. Interacting with Computers, 15, 429-452. McKinney, V., Kanghyun, Y., \& Fatemeh, Z. (2002). The measurement of Webcustomer satisfaction: An expectation and disconfirmation approach. Information Systems Review, 13(3), 296-315. 
Neuman, W, Lawrenece. 2000 Social Research Methods : Qualitative and Quantitative approach, $4^{\text {th }}$ Ed. Allyn \& Baccon/Pearson Boston

Nielsen, J. (1993). Usability Engineering. San Diego: Academic Press.

Peppard, Joe and Phillip Rowland, 1995, The Essence of Business Process Reengineering, Prentice Hall , United Kingdom.

Remenyi, dan Mpney, Arthur, Twite, Alan, 1995, Effective Measurement and Management of IT Cost and Benefits. Butterwoth - Heinemann, Oxford.

R.Hadikusuma, R.T Sutantya dan Dr. Sumantoro, 1991, Pengertian Pokok Hukum Perusahaan, Rajawali Press, Jakarta

Seddon, P, Peter and Kiew, Yen, Mien, 1996, A Partial Test and Development of DeLone and McLean's Model of IS Success.

Soedarisman, Huesodo, 2006, Menggapai Sejahtera Bersama KPWN, Koperasi Perumahan Wanabakti Nusantara, Jakarta.

Sugiyono, Drs, 2002 Metode Penelitian Bisnis, Cetakan Keempat, Penerbit PT Alfabeta, Jakarta.

Usman, Husein, dan Akbar, Setiady, Purnomo, R, 1995, pengantar statistika, Cetakan pertama, Penerbit Bumi aksara, Jakarta

Undang-Undang Republik Indonesia No.25 Tahun 1992

Webber, Ron, 1999, Information System Control and Audit, Prentice Hall, New Jersey.

Westbrook, R. A., et al. (1983). Value-percept disparity: An alternative to the

disconfirmation of expectations theory of consumer satisfaction. Advances in Consumer Research, 10, 256-261.

Wolfingbarger, M., \& Gilly, M. C. (2001). Shopping online for freedom, control, and fun. California Management Review, 43(2), 34-55. [online] available :

http://id.wikipedia.org/wiki/Koperasi [2008, Mei 14] 